\title{
Guillain-Barré syndrome and variants associated with SARS-CoV-2 infection in Mexico
}

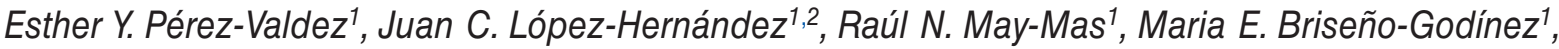 \\ Javier A. Galnares-Olalde¹, Jorge de-Saráchaga-Adib", Elizabeth León-Manríquez', \\ Juan M. Calleja-Castillo², José de J. Flores-Rivera ${ }^{3}$, and Edwin S. Vargas-Cañas ${ }^{1 *}$ \\ ${ }^{1}$ Neuromuscular Department; ${ }^{2}$ Neurological Emergencies Department; ${ }^{3}$ Clinical Neuroimmunology Department, National Institute of Neurology and \\ Neurosurgery "Manuel Velasco Suárez", Mexico City, Mexico
}

\begin{abstract}
Background: To date, Mexico has more than 1,280,000 confirmed cases and more than 116,000 deaths due to severe acute respiratory syndrome coronavirus 2 (SARS-CoV-2) infection. Limited information is available regarding Latin American patients with Guillain-Barré syndrome (GBS) and SARS-CoV-2. Objective: The objective is to describe the presentation, diagnosis, and outcome of patients with GBS associated with SARS-CoV-2 infection. Methods: We describe four cases of GBS associated with SARS-CoV-2 infection in Mexico. Results: Neurological symptoms initiated 2-17 days after the respiratory symptoms. The age group in or patients ranged from 26 to 41 years. Two patients presented with progressive, acute, and symmetric weakness and two with bilateral facial palsy. Patients with GBS diagnosis associated with SARS-CoV-2 infection have been reported to have a good outcome after IGIV or plasma exchange therapy. Conclusion: It is important to consider GBS as a potential manifestation of SARS-CoV-2 infection and recall that the diagnosis is based mainly on clinical evaluation. Laboratory and CSF analysis, as well as neurophysiologic studies, should be considered as a complement for diagnosis.
\end{abstract}

Key words: SARS-CoV-2. Guillain-Barré. Nerve conduction studies.

\section{Síndrome de Guillain-Barré y variantes asociadas a la infección por SARS-CoV-2 en México}

\section{Resumen}

Antecedentes: A la fecha, México tiene más de 1,280,000 casos confirmados y más de 116,000 muertes por infección por SARS-CoV-2. Se dispone de información limitada sobre los pacientes latinoamericanos con síndrome de Guillain-Barré (GBS) y SARS-CoV-2. Objetivo: El objetivo es describir la presentación, el diagnóstico y la evolución de los pacientes con síndrome de Guillain-Barré asociado a la infección por SARS-CoV-2. Métodos: Describimos cuatro casos de SGB asociados a la infección por SARS-CoV-2 en México. Resultados: Los síntomas neurológicos se iniciaron 2-17 días después de los síntomas respiratorios. El grupo de edad de los pacientes osciló entre 26 y 41 años. Dos pacientes presentaron debilidad progresiva, aguda y simétrica y dos con parálisis facial bilateral. Se ha reportado que los pacientes con diagnóstico de GBS asociado con la infección por SARS-CoV-2 tienen un buen resultado después de la terapia de recambio plasmático o IGIV.

Correspondence:

*Edwin S. Vargas-Cañas

E-mail: clinicaneuromuscular.innn@gmail.com

2604-6180/ (c) 2021 Academia Mexicana de Neurolo (http://creativecommons.org/licenses/by-nc-nd/4.0/)
Date of reception: $28-12-2020$

Date of acceptance: 16-03-2021

DOI: 10.24875/RMN.200001361
Available online: 25-05-2021 Rev Mex Neuroci. 2021;22(3):96-100 www.revmexneurociencia.com 
Conclusión: Es importante considerar el SGB como una posible manifestación de la infección por SARS-CoV-2 y recordar que el diagnóstico se basa principalmente en la evaluación clínica. Los análisis de laboratorio y de LCR, así como los estudios neurofisiológicos, deben considerarse como un complemento del diagnóstico.

Palabras clave: SARS-CoV-2. Guillain-Barré. Estudios de conducción nerviosa.

\section{Introduction}

In December 2019, several cases of severe pneumonia caused by a new virus belonging to the family Coronaviridae were reported in Wuhan, the capital city of Hubei Province in China ${ }^{1}$. On February 11, 2020, the virus was formally named as severe acute respiratory syndrome coronavirus 2 (SARS-CoV-2). The World Health Organization (WHO) on March 11, 2020, declared the novel coronavirus disease (COVID-19) outbreak a global pandemic, infecting more than 34 million people worldwide ${ }^{2}$. Unfortunately, the global death toll from COVID-19 has recently surpassed 1 million. To date, Mexico has more than 1,280,000 confirmed cases and more than 116,000 deaths $^{3}$.

Manifestations of SARS-CoV-2 infection include non-specific symptoms such as fever, headache, cough, myalgias, and olfactory disturbances. Some patients progress to severe respiratory failure that may lead to death. Neurological manifestations include cerebrovascular disease, encephalitis, myelitis, acute necrotizing myositis, para-infectious symptoms, and Guillain-Barré syndrome (GBS) ${ }^{4,5}$.

The first case of GBS associated with SARS-CoV-2 infection was reported in Wuhan in a woman who returned from China that presented acute lower extremity weakness and areflexia that progressed over 3 days to the arms without any systemic symptoms ${ }^{6}$. Following this case, Italy reported six cases of GBS associated with SARS-CoV-2 infection ${ }^{4,7}$. Limited information is available regarding Latin American patients with GBS and SARS-CoV-2. Hereby, we present four cases of GBS associated with SARS-CoV-2 infection in Mexico. Patient's characteristics are described in table 1.

\section{Case 1}

A 32-year-old woman presented to the emergency department with progressive and symmetrical weakness of all limbs that left her wheelchair bound in $48 \mathrm{~h}$. She also had cold sweats, fever, headache, and myalgias 6 days before neurological symptom onset. Neurological examination revealed quadriplegia and generalized areflexia. Admission chest computed tomography

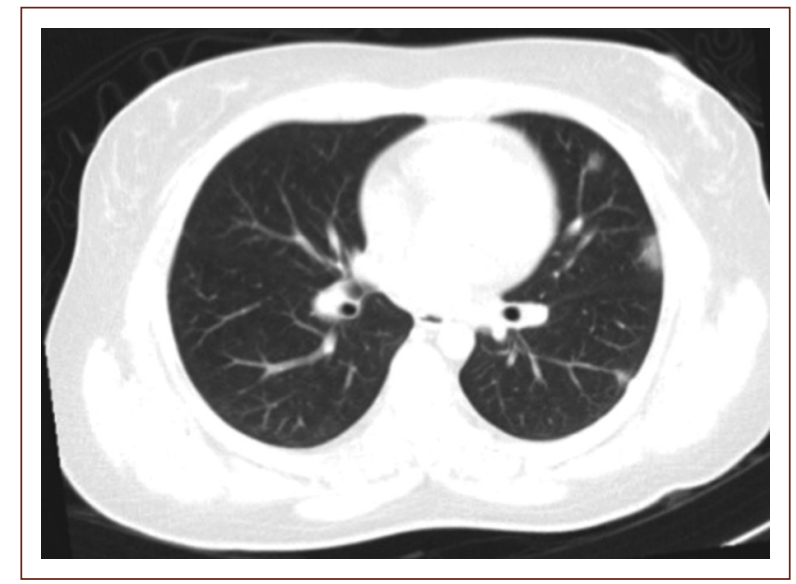

Figure 1. Patient 2 computed tomography showing multiple nodular infiltrates before to SARS-CoV-2 polymerase chain reaction confirmation.

found multiple reticular infiltrates (Fig. 1). Laboratory workup was normal, except for elevated lactic acid dehydrogenase (16, $080 \mathrm{IU} / \mathrm{L})$, D-dimer (1313 ng/dL), and creatine phosphokinase (3599 IU/L). Lumbar puncture was normal. SARS-CoV-2 nasopharyngeal reverse transcriptase-polymerase chain reaction (RT-PCR) testing was positive. Nerve conduction studies (NCSs) for motor (ulnar, median, peroneal, and tibial) and sensory nerves (median and sural) were reported as inexcitable. The patient received intravenous immunoglobulin (IVIG) and oxygen supplementation. In follow-up evaluation at 3 months, the patient was able to walk with assistance.

\section{Case 2}

A 41-year-old woman with chronic obstructive pulmonary disease history presented to the emergency department with a 4-day history of progressive and symmetrical weakness in all limbs (Fig. 2). Two days before neurological symptom onset, she presented olfactory disturbances, headache, and myalgias. Neurological examination revealed quadriplegia and generalized areflexia. Blood work-up, inflammatory markers, and lumbar puncture were normal. SARS-CoV-2 nasopharyngeal RT-PCR testing was positive. NCS 
Table 1. Characteristics of GBS patients associated with SARS-CoV-2 infection

\begin{tabular}{|c|c|c|c|c|}
\hline & Patient 1 & Patient 2 & Patient 3 & Patient 4 \\
\hline Age (years) & 32 & 41 & 40 & 26 \\
\hline Sex & $\mathrm{F}$ & $\mathrm{F}$ & M & M \\
\hline Comorbidities & None & COPD & Asthma & None \\
\hline Medication & None & None & None & None \\
\hline $\begin{array}{l}\text { Neurological } \\
\text { symptoms and signs }\end{array}$ & $\begin{array}{l}\text { Progressive and } \\
\text { symmetrical weakness } \\
\text { of all limbs ( } 72 \mathrm{~h})\end{array}$ & $\begin{array}{l}\text { Progressive and symmetrical } \\
\text { weakness of all limbs ( } 96 \mathrm{~h}), \\
\text { olfactory disturbances ( } 144 \mathrm{~h} \text { ) }\end{array}$ & $\begin{array}{l}\text { Bilateral facial palsy } \\
\text { and numbness of both } \\
\text { hands (17 days) }\end{array}$ & $\begin{array}{l}\text { Bilateral facial palsy } \\
\text { and numbness in both } \\
\text { hands ( } 7 \text { days) }\end{array}$ \\
\hline Respiratory failure & No & No & No & No \\
\hline Clinical GBS variant & Pure motor & Pure motor & $\begin{array}{l}\text { Bilateral facial palsy } \\
\text { with paresthesias }\end{array}$ & $\begin{array}{l}\text { Bilateral facial palsy } \\
\text { with paresthesias }\end{array}$ \\
\hline $\begin{array}{l}\text { Electrophysiological } \\
\text { variant }\end{array}$ & AIDP & Inexcitable & Not performed & Not performed \\
\hline CSF findings & Normal & Normal & Normal & Normal \\
\hline Treatment & IVIG & IVIG & Conservative & Conservative \\
\hline Outcome (Hughes) & Hughes 3 ( 3 months) & Hughes 1 (3 months) & Hughes 0 & Hughes 0 \\
\hline
\end{tabular}

Table 2. Electrophysiological findings in patients 1 and 2

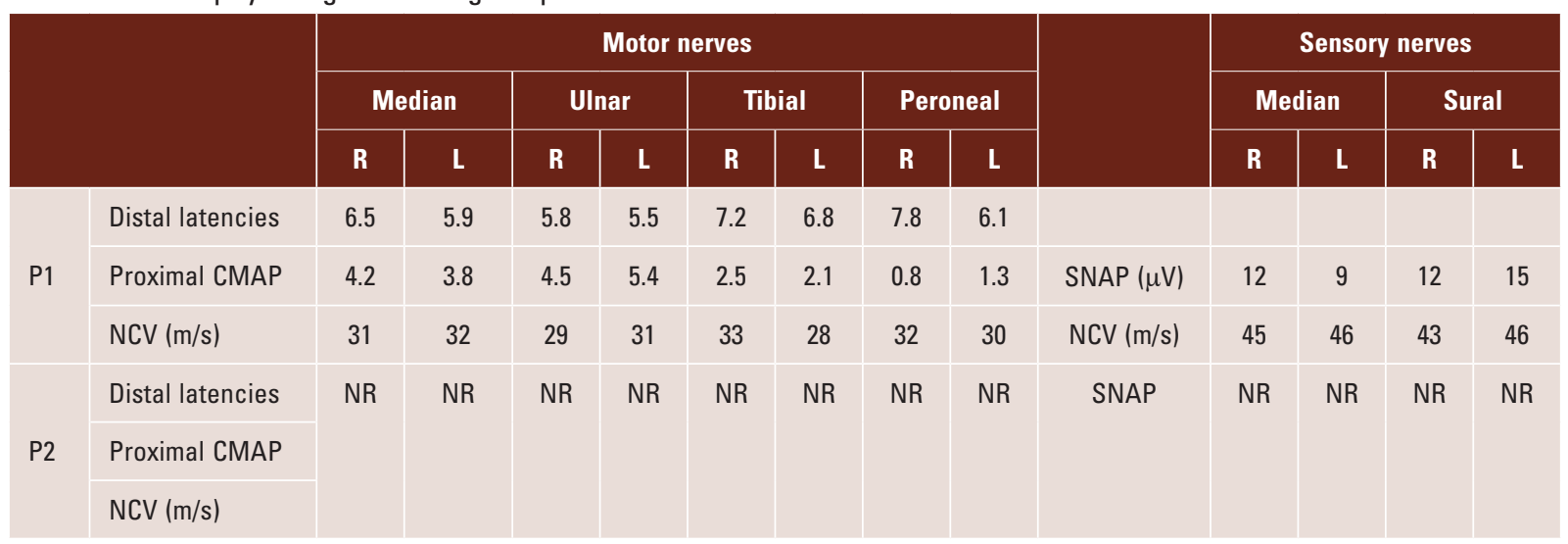

CMAP: compound muscle action potential; NCV: nerve conduction velocities; SNAP: sensory nerve action potential; NR: not registered; R: right; L: left.

demonstrated demyelinating features (Table 2). The patient received IVIG and oxygen supplementation. At 3-month follow-up evaluation, the patient was able to walk independently.

\section{Case 3}

A 40-year-old man with asthma history presented to the outpatient clinic with a 3-day history of olfactory and taste disturbances, headache, myalgias, cough, and sore throat. SARS-CoV-2 nasopharyngeal RT-PCR testing was positive. Seventeen days after COVID-related symptoms, he presented bilateral facial weakness and numbness in both hands. Neurological examination revealed bilateral facial palsy with normal strength and absent reflexes. Blood analysis and inflammatory markers were normal. Neither bulbar nerve involvement nor limb motor weakness was present, which led to conservative management with close surveillance. At 1-month follow-up evaluation, the patient persisted only with bilateral facial weakness. 


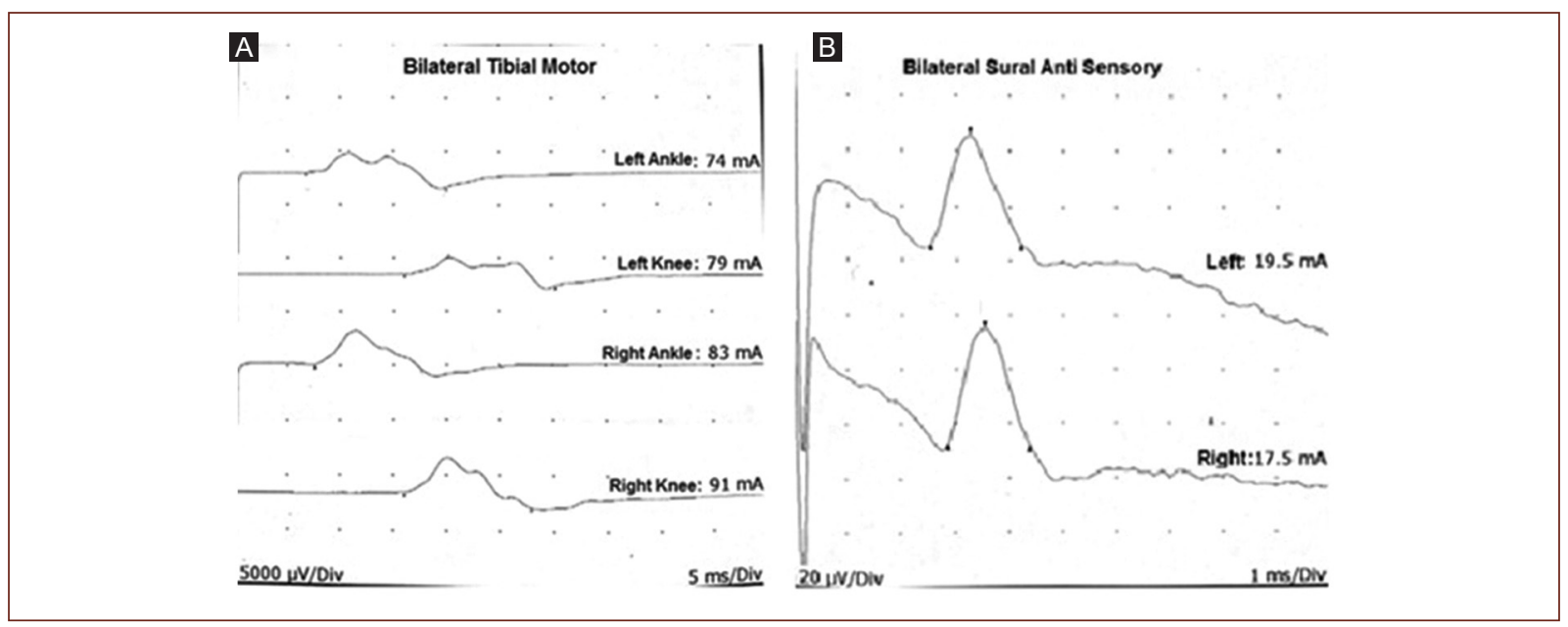

Figure 2. Nerve conduction curves for patient 1. A: Both motor tibial nerves showing increased latency and low compound muscle action potential values. B: Sural nerves with preserved sensory nerve action potentials.

\section{Case 4}

A 26-year-old man without relevant medical history presented to the emergency department due to a 7-day history bilateral facial weakness and numbness in both hands. He had a positive nasopharyngeal RT-PCR for SARS-CoV-2 9 days before neurological symptoms initiation. Neurological examination revealed bilateral facial weakness, normal strength, and generalized hyporeflexia. Blood analysis and inflammatory markers were normal. Like the previous case, neither bulbar nerve involvement nor limb motor weakness was present, which led to conservative management with close surveillance. At 1-month follow-up evaluation, the patient persisted only with bilateral facial weakness.

\section{Discussion}

GBS is an acute inflammatory polyradiculoneuropathy with a monophasic course. It is characterized by progressive, acute, and symmetrical weakness, sensory findings, occasional cranial nerve involvement, radicular pain, and absent reflexes ${ }^{8}$. GBS is caused by an abnormal autoimmune response against peripheral nerve gangliosides secondary to molecular mimicry. Up to $70 \%$ of the patients have a previous respiratory tract infection in the preceding 1-4 weeks ${ }^{9}$. GBS outbreaks have been described in association with epidemic and pandemic viral infections, such as influenza $A$ virus subtype H1N1 (A/H1N1), chikungunya virus, Zika virus,
Middle East respiratory syndrome-coronavirus, and SARS-CoV ${ }^{10}$.

To date, no viral SARS-CoV-2 particles have been found in peripheral nerves nor cerebrospinal fluid to establish a strictly direct association between GBS and COVID-19 infection. Ellul et al. defined as probable SARS-CoV-2-associated GBS when: (1) GBS symptoms appear within 6 weeks onset of acute SARS-CoV-2 infection; (2) either SARS-CoV-2 RNA detected in any sample or antibody evidence of acute SARS-CoV-2 infection; and (3) no evidence of other commonly associated causes ${ }^{11}$.

Most cases have been reported in Asian and European countries, such as China, Spain, and Italy, where SARS-CoV-2 community transmission is highest. The first GBS case associated with SARS-CoV-2 infection reported was a 61-year-old female with generalized weakness with absent reflexes. Afterward, six new cases were reported in Italy. Five patients had acute, progressive weakness, and paresthesia, while one patient had bilateral facial palsy and ataxia ${ }^{4,7}$.

At present, America has more SARS-CoV-2-positive cases for than other continents. We present four GBS cases related to SARS-CoV-2 infection in different health-care centers in Mexico. Neurological symptoms initiated 2-17 days after the respiratory symptoms. Common clinical findings in our patients were headache, fever, and myalgias. Toscano et al. reported in their series that the latency period between respiratory and neurological symptoms was 5-10 days ${ }^{11}$.

Cerebrospinal fluid SARS-CoV-2 PCR analysis was not performed in our patients. Nonetheless, in a 
systematic review that included 30 patients, all cases had a negative CSF report ${ }^{12}$. Thus, SARS-CoV-2-associated GBS pathophysiology may not be related to direct viral CSF presence in the nerve roots, but by an abnormal autoimmune response to systemic infection ${ }^{10}$. The age group in or patients ranged from 26 to 41 years, while worldwide reports present cases with patients older than 50 years ${ }^{13}$.

In our series, two patients presented with progressive, acute, and symmetric weakness and two with bilateral facial palsy. All patients had diminished or absent reflexes. These findings are consistent with clinical findings reported by Toscano ${ }^{7}$. Literature reports have identified AIDP, AMAN, and AMSAN subtypes in COVID-associated GBS patients. COVID-19 spike protein interacts with the GalNAc residue of GM1 and other gangliosides. After interaction, it anchors to cell surface gangliosides, causing a potential cross-reactivity with peripheral nerve glycolipids. We did not performed anti-gangliosides in our patients ${ }^{10}$. Patient 1 fulfilled electrophysiological criteria for AIDP variant, while patient 2 was classified as inexcitable. Both patients were treated with IGIV with improvement at 3-month follow-up. Nerve conduction studies were not performed in patients 3 and 4 . Furthermore, as both patients presented bilateral facial palsy and no strength compromise, the therapeutic approach was conservative. Patients with GBS diagnosis associated with SARS-CoV-2 infection have been reported to have a good outcome after IGIV or plasma exchange therapy ${ }^{11,13}$.

\section{Conclusion}

SARS-CoV-2 infection is an extremely contagious disease. Fortunately, GBS is likely to be seen increasingly in patients with SARS-CoV-2 infection with few or less severe features of COVID-19. The proportion of patients with GBS is small compared to respiratory manifestations. It is important to consider GBS as a potential manifestation of SARS-CoV-2 infection and recalls that the diagnosis is based mainly on clinical evaluation. Laboratory and CSF analysis, as well as neurophysiologic studies, should be considered as a complement to GBS diagnosis.

\section{Funding}

None to declare.

\section{Conflicts of interest}

The authors declare no conflicts of interest.

\section{Ethical disclosures}

Protection of human and animal subjects. The authors declare that no experiments were performed on humans or animals for this study.

Confidentiality of data. The authors declare that they have followed the protocols of their work center on the publication of patient data.

Right to privacy and informed consent. The authors have obtained the written informed consent of the patients or subjects mentioned in the article. The corresponding author is in possession of this document.

\section{References}

1. Hui DS, I Azhar E, Madani TA, Ntoumi F, Kock R, Dar O, et al. The continuing 2019-nCoV epidemic threat of novel coronaviruses to global health the latest 2019 novel coronavirus outbreak in Wuhan, China. Int J Infect Dis. 2020;91:264-6.

2. Baig AM, Khaleeq A, Ali U, Syeda H. Evidence of the COVID-19 virus targeting the CNS: tissue distribution, host-virus interaction, and proposed neurotropic mechanisms. ACS Chem Neurosci. 2020;11:995-8.

3. Secretaría de Salud, Gobierno de México. Informe Técnico Diario COVID-19 México. Consultado. Available from: https://www.gob.mx/cms/ uploads/attachment/file/581562/Comunicado_Tecnico_Diario_COVID-19 2020.09.30.pdf. [Last accessed on 2020 Sep 30].

4. Alberti $\mathrm{P}$, Beretta S, Piatti M, Karantzoulis A, Piatti ML, Santoro $P$, et al. Guillain-Barré syndrome related to COVID-19 infection. Neurol Neuroimmunol Neuroinflamm. 2020;7:e741.

5. Avula A, Nalleballe K, Narula N, Sapozhnikov S, Dandu V, Toom S, et al. COVID-19 presenting as stroke. Brain Behav Immun. 2020;87:115-9.

6. Zhao H, Shen D, Zhou H, Liu J, Chen S. Guillain-Barré syndrome associated with SARS-CoV-2 infection: causality or coincidence? Lancet Neurol. 2020;19:383-4.

7. Toscano G, Palmerini F, Ravaglia S, Ruiz L, Invernizzi P, Cuzzoni MG, et al. Guillain-Barré Syndrome Associated with SARS-CoV-2. N Engl J Med. 2020;382:2574-6.

8. Leonhard SE, Mandarakas MR, Gondim FAA, Bateman K, Ferreira MLB, Cornblath DR, et al. Diagnosis and management of Guillain-Barré syndrome in ten steps. Nat Rev Neurol. 2019;15:671-83.

9. Wilson $H$, Jacobs B, van Doorn P. Guillain barré syndrome. Lancet. 2016;388:717-27.

10. Dalakas MC. Guillain-Barré syndrome: The first documented COVID-19-triggered autoimmune neurologic disease: more to come with myositis in the offing. Neurol Neuroimmunol Neuroinflamm. 2020;7:e781.

11. Ellul MA, Benjamin L, Singh B, Lant S, Michael BD, Easton A, et al. Neurological associations of COVID-19. Lancet Neurol. 2020;19:767-83.

12. Neumann B, Schmidbauer ML, Dimitriadis K, Otto S, Knier B, Niesen WD, et al. Cerebrospinal fluid findings in COVID-19 patients with neurological symptoms. J Neurol Sci. 2020;418:117090.

13. Abu-Rumeileh S, Abdelhak A, Foschi M, Tumani H, Otto M. Guillain-Baré syndrome spectrum associated with COVID-19: an up-to-date systematic review of 73 cases. J Neurol. 2020;2020:1-38. 